\title{
Gejala konjungtivitis pada pasien dengan COVID-19: sebuah tinjauan sistematis
}

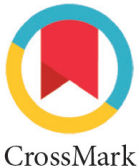

CrossMark
INTISARI SAINS MEDIS

Published by Intisari Sains Medis

\author{
Anggari Purnama Dewi ${ }^{1 *}$
}

\section{ABSTRACT}

Background: Infection of severe acute respiratory coronavirus syndrome 2 (SARS-CoV-2) or Coronavirus disease 2019 (COVID-19) has become a global pandemic. The clinical symptoms are not typical, making clinical diagnosis difficult to do. A number of studies have stated that ocular involvement in the form of conjunctivitis can be one of the symptoms of COVID-19 infection. The purpose of this systematic review is to determine the symptoms of conjunctivitis in patients with COVID-19 infection.

Methods: A systematic literature review was carried out by searching the literature on the Cochrane Library, Pubmed, and Google Scholar, also selecting the literature using the PRISMA diagram. The inclusion criteria used were studies that examined the symptoms of conjunctivitis in COVID-19 patients published in the range of 2020-2021. Studies in the form of editorials, commentaries, reviews or meta-analyses, articles are not available in full-text, not available in English or Indonesian, do not discuss ocular manifestations of COVID-19 infection, or only discuss the detection of

the SARS CoV-2 virus in conjunctival secretions. So that there were 12 studies that met the eligibility criteria. Results: There were 12 studies that carried out synthetic analysis, namely 4 cross-sectional studies, one casecontrol study, one case series study, and six case reports. The prevalence of conjunctivitis symptoms in COVID-19 infection ranges from $5.04-31.75 \%$. Conjunctivitis is more common in male COVID-19 patients, with mild to moderate symptoms and duration of illness ranging from 5-26 days. Conjunctivitis in COVID-19 patients was reported as an early symptom of COVID-19 infection and the data became the sole symptom of COVID-19 infection. The habit of rubbing the eyes, impaired smell and taste were found to be significantly associated with conjunctivitis symptoms.

Conclusion: Although conjunctivitis is found in only a minority of COVID-19 cases, the conjunctiva can be one of the routes of transmission of COVID-19 infection. The use of goggles and face shields is important as an effort to prevent infection transmission.
'Dokter Umum, Departemen Ilmu Kesehatan Mata, Rumah Sakit Umum Daerah Klungkung, Bali, Indonesia;

\footnotetext{
*Korespondensi:

Anggari Purnama Dewi;

Dokter Umum, Departemen IImu Kesehatan Mata, Rumah Sakit Umum Daerah Klungkung, Bali, Indonesia;

purnamadewianggari@gmail.com
}

Keywords: COVID-19, clinical features, conjunctivitis, ocular manifestations, SARS CoV-2.

Cite This Article: Dewi, A.P. 2021. Gejala konjungtivitis pada pasien dengan COVID-19: sebuah tinjauan sistematis. Intisari Sains Medis 12(2): 645-652. D0I: 10.15562/ism.v12i2.1000

\section{ABSTRAK}

Latar Belakang: Infeksi severe acute respiratory syndrome coronavirus 2 (SARS-CoV-2) atau Coronavirus disease 2019 (COVID-19) telah menjadi pandemi global. Gejala klinisnya yang tidak khas membuat penegakkan diagnosis klinis sulit dilakukan. Sejumlah studi menyebutkan keterlibatan okuler berupa konjungtivitis dapat menjadi salah satu gejala infeksi COVID-19. Tujuan dari systematic review ini adalah untuk mengetahui gejala konjungtivitis pada pasien dengan infeksi COVID-19.

Metode: Tinjauan pustaka sistematis dilakukan dengan pencarian literatur pada Cochrane Library, Pubmed dan Google Scholar, juga pemilihan literatur menggunakan diagram PRISMA. Kriteria inklusi yang digunakan adalah studi yang meneliti gejala konjungtivitis pada pasien COVID-19 yang terpublikasi pada rentang tahun 2020-2021. Studi berupa editorial, commentary, review maupun meta analisis, artikel tidak tersedia secara full-text, tidak tersedia dalam Bahasa Inggris atau Indonesia, tidak membahas manifestasi okuler pada infeksi COVID-19, atau hanya membahas mengenai deteksi virus SARS CoV-2 pada sekresi konjungtiva dilakukan eksklusi sehingga didapatkan 12 studi yang memenuhi kriteria eligibilitas.

Hasil: Terdapat 12 studi yang dilakukan analisis sintesis, yakni 4 studi cross sectional, satu studi kasus kontrol, satu studi serial kasus dan enam laporan kasus. Prevalensi gejala konjungtivitis pada infeksi COVID-19 berkisar 5,04-31,75\%. Konjungtivitis lebih banyak ditemukan pada pasien COVID-19 berjenis kelamin lakilaki, dengan gejala ringan sedang dan durasi penyakit berkisar 5-26 hari. Konjungtivitis pada pasien COVID-19 dilaporkan sebagai gejala awal infeksi COVID-19 dan data menjadi gejala tunggal infeksi COVID-19. 
Kebiasaan menggosok mata, gangguan penciuman dan pengecap ditemukan signifikan berhubungan dengan gejala konjungtivitis.

Simpulan: Meskipun konjungtivitis ditemukan hanya pada sebagian kecil kasus COVID-19, konjungtiva dapat menjadi salah satu rute transmisi infeksi COVID-19. Penggunaan goggles dan face shield penting dilakukan sebagai upaya pencegahan transmisi infeksi.

Kata kunci: COVID-19, gambaran klinis, konjungtivitis, manifestasi okuler, SARS CoV-2.

Sitasi Artikel ini: Dewi, A.P. 2021. Gejala konjungtivitis pada pasien dengan COVID-19: sebuah tinjauan sistematis. Intisari Sains Medis 12(2): 645-652. D0I: 10.15562/ism.v12i2.1000

\section{LATAR BELAKANG}

Infeksi severe acute respiratory syndrome coronavirus 2 (SARS-CoV-2) atau Coronavirus disease 2019 (COVID-19) yang pertama kali ditemukan pada akhir 2019 di kota Wuhan, Cina hingga kini telah menyebar luas dan menjadi pandemi global sejak Maret 2020. ${ }^{1}$ Infeksi COVID-19 utamanya menyerang organ paru dimana derajat terberat infeksi COVID-19 ditandai dengan adanya pneumonia berat, gejala acute repiratory distress syndrome (ARDS) dan kondisi hiperkoagulasi. ${ }^{1}$ Penegakkan diagnosis klinis infeksi COVID-19 menimbulkan suatu tantangan, sebab tidak adanya gejala patognomonik untuk deteksi penyakit ini. Infeksi COVID-19 dapat disebut sebagai imitator berbagai jenis penyakit, akibat spektrum gejala yang ditimbulkan sangat luas mulai dari batuk, demam, lemas, nyeri tenggorokan, sesak nafas, sakit kepala hingga gejala gastrointestinal seperti diare, nyeri perut, penurunan nafsu makan, dan mual muntah. ${ }^{2,3}$

Sampai saat ini, rute transmisi COVID-19 masih belum diketahui dengan jelas. Hingga saat ini studi menunjukkan bahwa saluran napas merupakan satusatunya rute transmisi virus ini, namun beberapa peneliti mengajukan hipotesis bahwa droplet COVID-19, tangan yang telah terinfeksi, dan juga konjungtiva mata yang telah terkontaminasi, dapat menjadi lokasi awal penyebaran infeksi. ${ }^{3}$ Konjungtivitis merupakan penyakit pada mata yang sangat sering ditemui, dapat disebabkan infeksi virus atau bakteri. Sejumlah studi menunjukkan bahwa konjungtivitis dapat menjadi manifestasi klinis COVID-19. Seperti studi oleh Douglas dkk. dan Wu dkk. yang meneliti karakteristik okuler pasien COVID-19, menemukan adanya peningkatan insiden konjungtivitis seiring dengan keparahan penyakit. ${ }^{4,5}$

Sebagian besar penelitian mengenai infeksi COVID-19 berfokus pada manifestasi repiratorik, namun beberapa bukti menunjukkan adanya keterlibatan okuler pada manifestasi klinis COVID-19. Manifestasi okuler yang timbul disebutkan beragam mulai dari mata kering, sensasi benda asing pada mata, kimosis, fotofobia, dan konjungtivitis. ${ }^{1,2}$ Beberapa studi bahkan menunjukkan bahawa konjungtivitis merupakan gejala awal infeksi COVID-19. Hasil penelitian oleh The Lancet pada Februari 2020 menyatakan bahwa permukaan mata dapat menjadi target potensial untuk invasi virus COVID-19. ${ }^{6}$ Namun dua penelitian terbaru tidak mendukung asumsi ini yakni berkaitan dengan penelitian oleh Sarma dkk. dan Zhou dkk., dengan sebagian kecil pasien dengan COVID-19 mengalami gejala konjungtivitis dan tidak semua pasien tersebut menunjukkan hasil positif COVID-19 dari pemeriksaan swab konjungtiva. ${ }^{7,8}$ Teori menunjukkan bahwa virus COVID-19 berikatan dengan human angiotensin-enzyme II (ACE2) dan menggunakannya sebagai jalan masuk untuk menginvasi sel epitel paru dan saluran napas melalui spike (S) protein. Perlu diketahui pula bahwa ACE2 sebagian besar juga diekspresikan pada sel epitel kornea dan konjungtiva mata. ${ }^{89}$ Diketahuinya prevalensi konjungtivitis sebagai manifestasi klinis COVID-19 dapat membantu tenaga medis dalam mendiagnosis penyakit ini lebih cepat dan tepat. Oleh karena itu, systematic review ini bertujuan untuk merangkum literaturliteratur yang relevan dengan gejala konjungtivitis pada pasien dengan infeksi COVID-19.

\section{METODE}

\section{Strategi Pencarian}

Pencarian literatur dilakukan pada basis data publikasi ilmiah seperti Cochrane library, Pubmed dan Google scholar dengan menggunakan operator Boolean. Adapun kata kunci yang digunakan adalah [(conjunctivitis OR eye infection $\mathrm{OR}$ okuler manifestation) AND (COVID-19 OR SARS-CoV-2)]. Rentang studi dibatasi sejak tahun 2020 hingga 2021.

\section{Kriteria Eligibilitas}

Untuk kriteria eligibilitas diterapkan pemilihan studi dengan menggunakan diagram PRISMA. Pada tahap awal untuk menskrining literatur yang diperoleh dari pencarian basis data online sesuai dengan kata kunci yang telah kami tetapkan. Setelah itu dilakukan eliminasi temuan dengan judul yang tidak relevan, serta studi-studi yang terduplikasi. Pada tahap kedua dilakukan penilaian abstrak dan naskah lengkap literatur. Pada penilaian tahap kedua ini dilakukan penetapan naskah yang akan diikutkan dalam analisis menggunakan kriteria inklusi dan eksklusi.

Kriteria inklusi yang kami gunakan adalah studi observasional empiris dengan desain berupa studi crosssectional, kontrol-kasus, kohort, uji klinis, maupun laporan kasus mengenai gejala konjuntivitis yang ada pada pasien COVID-19. Adapun kriteria eksklusi yang kami gunakan adalah studi berupa editorial, commentary, review maupun meta-analisis, studi yang tidak tersedia secara full-text, studi yang tidak tersedia dalam Bahasa Inggris atau Indonesia, studi yang tidak membahas manifestasi okuler pada infeksi COVID-19, dan studi yang membahas mengenai deteksi virus SARS 


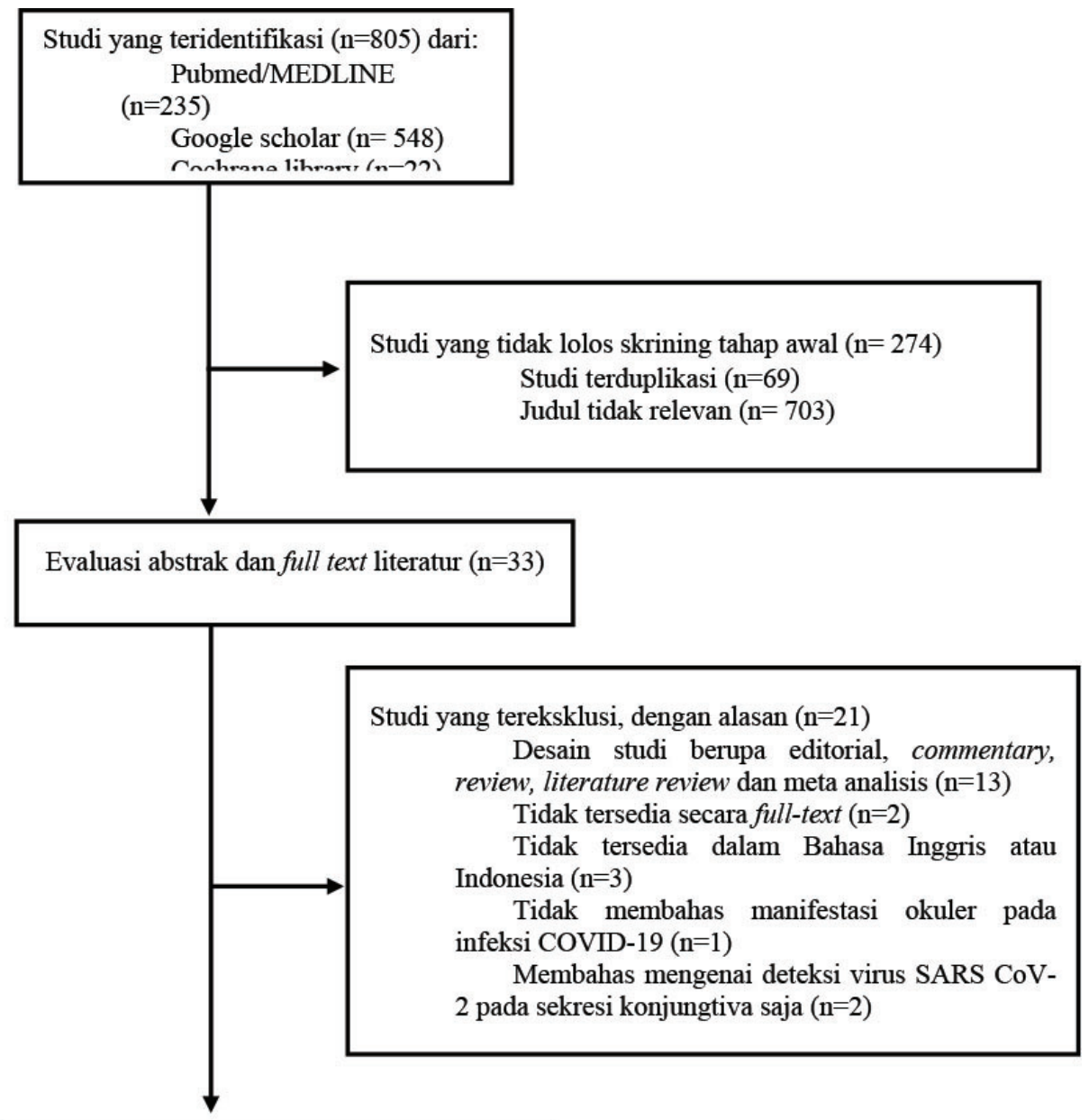

Studi yang memenuhi kriteria eligibilitas dan diikutsertakan dalam analisis $(\mathrm{n}=12)$

Gambar 1. Diagram PRISMA studi.

CoV-2 pada sekresi konjungtiva saja. Setelahnya dilakukan telaah studi mulai dari skrining tahap awal pada judul untuk mencegah duplikasi studi hingga evaluasi eligibilitas studi sebelum diikutkan ke dalam tahap sintesis.

\section{Pengumpulan Data}

Literatur yang diidentifikasi kemudian digabung dan dikelola untuk analisis lebih lanjut. Semua literatur yang dipilih dibaca secara menyeluruh dan didalami untuk mendapatkan intisari literatur.

\section{Sintesis Data}

Semua studi yang relevan melaporkan gejala konjungtivitis pada COVID-19 dimasukkan dalam sintesis naratif. Sebagai suatu penelitian kualitatif, systematic review ini mencoba menjelaskan temuan mengenai deteksi virus SARS CoV-2 pada sekresi konjungtiva saja sehingga pada tahap akhir didapatkan 12 buah studi yang diikutkan dalam analisis sintesis seperti yang ditunjukkan pada diagram PRISMA (Gambar 1).

\section{Karakteristik Studi}

12 studi yang diikutsertakan dalam analisis systematic review ini memiliki kualitas studi baik berdasarkan penilaian menggunakan checklist dari the Joanna Briggs Institute. Didapatkan sebanyak 4 studi cross-sectional, 1 studi kontrolkasus, 1 serial kasus dan 6 buah laporan kasus. Studi-studi tersebut dilakukan dalam rentang waktu tahun 2020-2021 di negara-negara seperti Cina, India, Israel, Spanyol, Brazil, Perancis, Italia dan Turki. Total dilibatkan sebanyak 1.076 sampel pasien dengan 1.044 pasien dengan infeksi COVID-19 dan pasien kontrol sebanyak 32 orang. Detail karakteristik masingmasing studi dapat dilihat pada Tabel 1 .

\section{Penilaian kualitas studi}

Penilaian kualitas studi menggunakan checklist dari the Joanna Briggs Institute disesuaikan dengan desain studi dari masing-masing literatur. Dari 12 studi yang diikutkan dalam analisis sebanyak 4 studi merupakan studi cross sectional, satu studi kontrol-kasus, satu studi serial kasus dan enam laporan kasus. Masingmasing item pada ceklis memiliki poin satu. Studi dinyatakan berkualitas baik apabila memiliki poin lebih dari atau sama dengan dari setengah nilai maksimum, dan dinyatakan berkualitas rendah apabila memiliki poin kurang dari setengah niai maksimum. Rentang nilai maksimum adalah 0-8 untuk studi sross sectional dan laporan kasus dan 0-10 untuk studi kontrol kasus dan serial kasus. Penilaian kualitas studi dilakukan oleh dua orang peneliti secara independen untuk mengurangi bias. Dari 12 studi yang dilibatkan didapatkan hasil penilaian baik untuk keseluruhan studi dengan rentang nilai 6-8.

\section{Karakteristik dan Prevalensi Gejala Konjungtivitis pada Pasien dengan Infeksi COVID-19}

Total keseluruhan sampel dari dua belas studi dalam systematic review ini adalah 
Tabel 1. Karakteristik masing-masing studi

\begin{tabular}{|c|c|c|c|}
\hline $\begin{array}{l}\text { Peneliti dan } \\
\text { Judul studi }\end{array}$ & Sampel studi & Tujuan penelitian & Temuan \\
\hline \multicolumn{4}{|l|}{ Cross Sectional } \\
\hline $\begin{array}{l}\text { Chen dkk., 2020, } \\
\text { Cina }^{10}\end{array}$ & $\begin{array}{l}535 \text { pasien COVID-19 di RS } \\
\text { Mobile Cabin dan Tongji }\end{array}$ & $\begin{array}{l}\text { Meneliti manifestasi okuler dan } \\
\text { karakteristik klinis pasien COVID-19. }\end{array}$ & $\begin{array}{l}\text { Sebanyak } 27 \text { pasien (5\%) mengalami } \\
\text { konjuntivitis dan } 4 \text { diantaranya mengalami } \\
\text { konjuntivitis sebagai gejala awal COVID-19. } \\
\text { Gejala okuler lain yang ditemukan pada } \\
\text { pasien COVID-19 dengan konjungtivitis } \\
\text { adalah peningkatan sekresi konjungtiva, } \\
\text { nyeri mata, fotofobia dan mata kering. }\end{array}$ \\
\hline $\begin{array}{l}\text { Zhou dkk., 2020, } \\
\text { China }^{8}\end{array}$ & $\begin{array}{l}121 \text { pasien COVID-19 di RS } \\
\text { Renmin Universitas Wuhan. }\end{array}$ & $\begin{array}{l}\text { Mengetahui karakteristik gejala okuler } \\
\text { dan pemeriksaan swab konjungtiva } \\
\text { untuk mendeteksi SARS-CoV-2 serta } \\
\text { melihat korelasi antara temuan okuler } \\
\text { dengan durasi penyakit. }\end{array}$ & $\begin{array}{l}\text { Dari } 121 \text { paisen, hanya } 8 \text { pasien mengalami } \\
\text { gejala konjungtivitis dan hanya } 1 \text { pasien } \\
\text { menunjukkan hasil positif SARS-CoV-2 pada } \\
\text { konjungtiva. }\end{array}$ \\
\hline $\begin{array}{l}\text { Sindhuja dkk., 2020, } \\
\text { India }^{11}\end{array}$ & $\begin{array}{l}27 \text { pasien COVIFD-19 gejala } \\
\text { ringan di RS tersier India } \\
\text { Utara }\end{array}$ & $\begin{array}{l}\text { Mengetahui gejala klinis dan } \\
\text { prevalensi konjuntivitis serta } \\
\text { manifestasi okuler lainnya pada } \\
\text { pasien COVID-19 dengan gejala } \\
\text { ringan. }\end{array}$ & $\begin{array}{l}\text { Sebanyak } 12(9,45 \% \text { pasien mengalami } \\
\text { keluhan pada mata, } 11(8,66 \%) \text { mengalami } \\
\text { keluhan saat MRS. Dari } 11 \text { pasien tersebut, } 8 \\
(6,29 \%) \text { mengalami konjungtivitis. }\end{array}$ \\
\hline $\begin{array}{l}\text { Güemes-Villahoz } \\
\text { dkk., 2020, Spanyol }{ }^{12}\end{array}$ & 301 pasien COVID-19 & $\begin{array}{l}\text { Mengevaluasi frekuensi dan gejala } \\
\text { klinis konjungtivitis pada pasien } \\
\text { OVID-19 yang dirawat di RS. }\end{array}$ & $\begin{array}{l}\text { Sebanyak } 35(11,6 \%) \text { pasien mengalami } \\
\text { konjuntivitis akut. Tidak terdapat hubungan } \\
\text { antara keparahan COVID-19 dengan } \\
\text { kejadian konjuntivitis }(\mathrm{p}=0,17) \text {. }\end{array}$ \\
\hline \multicolumn{4}{|l|}{ Kontrol-kasus } \\
\hline $\begin{array}{l}\text { Shemer dkk., 2021, } \\
\text { Israel }^{13}\end{array}$ & $\begin{array}{l}\text { Total } 48 \text { sampel, } 16 \\
\text { konfirmasi positif } \\
\text { COVID-19 dan } 32 \text { orng } \\
\text { control. }\end{array}$ & $\begin{array}{l}\text { Menilai keterlibatan okuler pada } \\
\text { pasien positif COVID-19 di fasilitas } \\
\text { kesehatan tersier. }\end{array}$ & $\begin{array}{l}\text { Injeksi konjuntiva ditemukan pada } 3(19 \%) \\
\text { pasien COVID-19 dibandingkan kelompok } \\
\text { control ( } \mathrm{p}=0,034) \text {. Dibandingkan kelompok } \\
\text { control, pasien dengan COVID-19 lebih } \\
\text { banyak mengalami keluhan adanya sensasi } \\
\text { benda asing pada mata ( } 31,3 \% \text { vs } 3,1 \%, \mathrm{p} \\
=0,005) \text { dan mata merah ( } 25 \% \text { vs } 0 \%, \mathrm{p}= \\
\text { 0,003). Injeksi konjungtiva juga berhubungan } \\
\text { dengan anosmia dan ageusia ( } 75 \% \text { vs } 7,7 \% \text {, } \\
\mathrm{p}=0,018) \text {. }\end{array}$ \\
\hline
\end{tabular}

\begin{tabular}{|c|c|c|}
\hline \multicolumn{3}{|c|}{ Case report/case-series } \\
\hline $\begin{array}{l}\text { Wu dkk., 2020, } \\
\text { China }^{5}\end{array}$ & 38 pasien COVID-19 & $\begin{array}{l}\text { Mengetahui manifestasi okuler dan } \\
\text { prevalensi virus pada konjungtiva } \\
\text { pasien COVID-19. }\end{array}$ \\
\hline
\end{tabular}

Marquezan dkk., 2020, Brazil ${ }^{14}$

Daruich dkk., 2020, Argentina $^{15}$

Nayak dkk., 2020, India $^{16}$

Navel dkk., 2020, Perancis $^{17}$

Laki-laki 24 tahun dengan konjungtivitis bilateral dan positif COVID-19.

Melaporkan kasus konjungtivitis bilateral pada pasien terkonfirmasi COVID-19.

Laki-laki 27 tahun positif COVID-19 dengan keluhan sensasi benda asing dan kemerahan pada mata Satu pasien laki-laki 65 tahun

Satu pasien laki-laki 63 tahun

Scalinci dkk., 2020, Lima pasien COVID-19 Italia $^{18}$
Melaporkan kasus pasien dengan manifestasi okuler yang kemudian terkonfirmasi COVID-19.

Melaporkan kasus COVID-19 pada pasien dengan komorbid DM, hipertensi, asma dan konjungtivitis

Melaporkan manifestasi okuler berupa konjungtivitis hemoragik pada pasien COVID-19 yang dirawat di ICU. dengan gejala atipikal yang melibatkan mata. folikular pada mata kanan.

Melaporkan 5 kasus COVID-19
12 dari 38 pasien memiliki manifestasi okuler berupa konjungtivitis dan juga hiperemi konjungtiva, kimosis, epifora dan peningkatan sekresi konjungtiva.

Infeksi COVID-19 gejala ringan dapat menyebabkan konjungtivitis bilateral.

Konjuntivitis dapat menjadi gejala awal infeksi COVID-19.

Konjungtivitis terjadi pada tahap akhir penyakit dan mengalami resolusi dengan cepat.

Virus SARS-CoV-2 dapat ditemukan pada air mata dan sekret konjungtiva, infeksi okuler eksternal dapat menjadi faktor penyebaran infeksi.

Konjungtivitis dapat menjadi gejala awal dan juga satu-satunya manifestasi klinis infeksi COVID-19. 
Peneliti dan Judul studi

Ozturker, 2020 Turki ${ }^{19}$
Sampel studi

Satu pasien wanita 32 tahun

Melaporkan kasus infeksi COVID-19 dengan gejala klinis konjungtivitis saja.

Tujuan penelitian
Temuan

Konjungtivitis dapat menjadi gejala tunggal infeksi COVID-19 dimana pasien tidak mengalami demam, lemas, dan gejala respiratorik yang mnerahakan kecurigaan kepada infeksi COVID-19.

Tabel 2. Karakteristik gejala konjungtivitis pada pasien dengan infeksi COVID-19

\begin{tabular}{|c|c|c|c|c|}
\hline \multirow{2}{*}{ Studi } & \multirow{2}{*}{ Kejadian konjungtivitis } & \multirow{2}{*}{ Durasi konjungtivitis } & \multicolumn{2}{|c|}{ Derajat COVID-19 } \\
\hline & & & Ringan-sedang & Berat \\
\hline Chen $\mathrm{dkk}^{\mathrm{a}}$ & $27 / 535(5,04 \%)$ & $5,9 \pm 4,5$ hari & $\mathrm{N} / \mathrm{A}$ & $\mathrm{N} / \mathrm{A}$ \\
\hline Zhou dkk ${ }^{\mathrm{a}}$ & $8 / 121(6,6 \%)$ & N/A & 1 & 7 \\
\hline Shinduja dkk ${ }^{\mathrm{a}}$ & $8 / 127(6,3 \%)$ & $\mathrm{N} / \mathrm{A}$ & 8 & 0 \\
\hline Güemes-Villahoz dkk ${ }^{\mathrm{a}}$ & $35 / 301(11,6 \%)$ & 3 hari & 25 & 10 \\
\hline Shemer $\mathrm{dkk}^{\mathrm{b}}$ & $3 / 16(18,75 \%)$ & $\mathrm{N} / \mathrm{A}$ & $\mathrm{N} / \mathrm{A}$ & $\mathrm{N} / \mathrm{A}$ \\
\hline Wu dkk ${ }^{c}$ & $12 / 38(31,75 \%)$ & $\mathrm{N} / \mathrm{A}$ & 4 & 8 \\
\hline Marquezan $\mathrm{dkk}^{\mathrm{d}}$ & 1 & 10 hari & 1 & 0 \\
\hline Daruich $\mathrm{dk}^{\mathrm{d}}$ & 1 & 11 hari & 1 & 0 \\
\hline Nayak dkk ${ }^{\mathrm{d}}$ & 1 & 5 hari & 0 & 1 \\
\hline Navel dkk ${ }^{\mathrm{d}}$ & 1 & 26 hari & 0 & 1 \\
\hline Scalinci $\mathrm{dkk}^{\mathrm{d}}$ & 5 & N/A & 5 & 0 \\
\hline Ozturker $^{\mathrm{d}}$ & 1 & $\mathrm{~N} / \mathrm{A}$ & $\mathrm{N} / \mathrm{A}$ & $\mathrm{N} / \mathrm{A}$ \\
\hline \multicolumn{5}{|c|}{${ }^{\mathrm{a}}=$ studi cross sectional, ${ }^{\mathrm{b}}=$ studi ontrol kasus, ${ }^{\mathrm{c}}=$ studi serial kasus, ${ }^{\mathrm{d}}=$ studi laporan kasus, N/A $=$ tidak ada data } \\
\hline
\end{tabular}

1.076 sampel, dimana sebanyak 1.044 sampel dengan infeksi COVID-19 dan 32 sampel merupakan kelompok kontrol tanpa infeksi COVID-19. Sebanyak 689 (64\%) sampel berjenis kelamin lakilaki dan 389 (36\%) berjenis kelamin perempuan. Dari 1.044 sampel dengan infeksi COVID-19 sebanyak 103 (9,8\%) mengalami gejala konjungtivitis sebagai manifestasi klinis infeksinya.

Berdasarkan 4 studi cross-sectional, 1 studi kasus-kontrol, dan 1 serial kasus yang dilibatkan dalam systematic review ini, didapatkan prevalensi konjungtivitis pada infeksi COVID-19 adalah sebesar $5,04 \%, \quad 6,6 \%, \quad 6,3 \%, \quad 11,6 \%, \quad 18,75 \%$, dan $31,57 \% .^{8,10-12}$ Sedangkan dari segi durasi didapatkan durasi terjadinya konjungtivitis pada pasien dengan infeksi COVID-19 dari awal muncul gejala hingga resolusi gejala paling cepat adalah 3 hari dan paling lama 26 hari. Konjungtivitis lebih banyak ditemukan pada pasien dengan infeksi COVID-19 gejala ringan-sedang dibandingkan dengan gejala berat $(45(62,5 \%)$ vs 27 $(37,5 \%))$ seperti yang ditunjukkan pada Tabel 2. Hanya 1 studi yakni laporan kasus oleh Navel dkk. yang melaporkan adanya konjungtivitis hemoragik pada pasien dengan COVID-19 gejala berat yang dirawat di ICU. ${ }^{17} 3$ studi menyatakan bahwa konjungtivitis merupakan gejala awal infeksi COVID-19 yakni laporan kasus oleh Daruich dkk., Scalinci dkk., dan Ozturker dkk. dimana studi oleh Scalinci dkk. dan Ozturker dkk. juga menemukan konjungtivitis sebagai satu-satunya gejala infeksi COVID-19. ${ }^{15,18,19}$

Penelitian oleh Chen dkk. yang melibatkan paling banyak sampel, yakni 535 pasien terkonfirmasi COVID-19 di RS Mobile Cabin Tongji, China, menemukan faktor risiko terjadinya konjungtivitis pada pasien COVID-19 adalah tingginya frekuensi menggosok mata. Dari 19 pasien yang sering menggosok mata dengan tangan, 13 diantaranya tidak mencuci tangan terlebih dahulu. ${ }^{10}$ Namun temuan ini berbeda dengan hasil dari Sindhuja dkk. yang menyatakan tidak ada hubungan signifikan antara kebiasaan menggosok mata dengan konjungtivitis. ${ }^{11}$ Temuan menarik lainnya didapatkan pada studi kasus-kontrol oleh Shemer dkk. Dalam studinya disebutkan gejala konjungtivitis berhubungan signifikan dengan adanya anomia dan ageusia pada pasien COVID-19. ${ }^{13}$

\section{DISKUSI}

Konjungtivitis merupakan suatu peradangan pada selaput bening mata atau konjungtiva yang dapat disebabkan oleh infeksi virus, bakteri, atau alergi. Sejumlah studi menyatakan bahwa gejala konjungtivitis merupakan manifestasi klinis yang jarang namun dapat ditemukan pada pasien dengan infeksi COVID-19. ${ }^{1-3}$ Berdasarkan hasil analisis prevalensi pada keenam studi, didapatkan prevalensi konjungtivitis berkisar antara 5,04-31,75\%. Prevalensi ditemukannya gejala konjungtivitis pada pasien infeksi COVID-19 memang tidak terlalu besar. Namun hal ini dapat menjadi acuan kita untuk meneliti lebih lanjut lagi mengenai konjungtiva mata sebagai salah satu rute transmisi infeksi COVID-19 selain melalui saluran napas. Chen dkk. yang meneliti gejala konjungtivtis pada 535 pasien COVID-19 di RS Moile Cabin dan Tongji China menemukan hubungan 


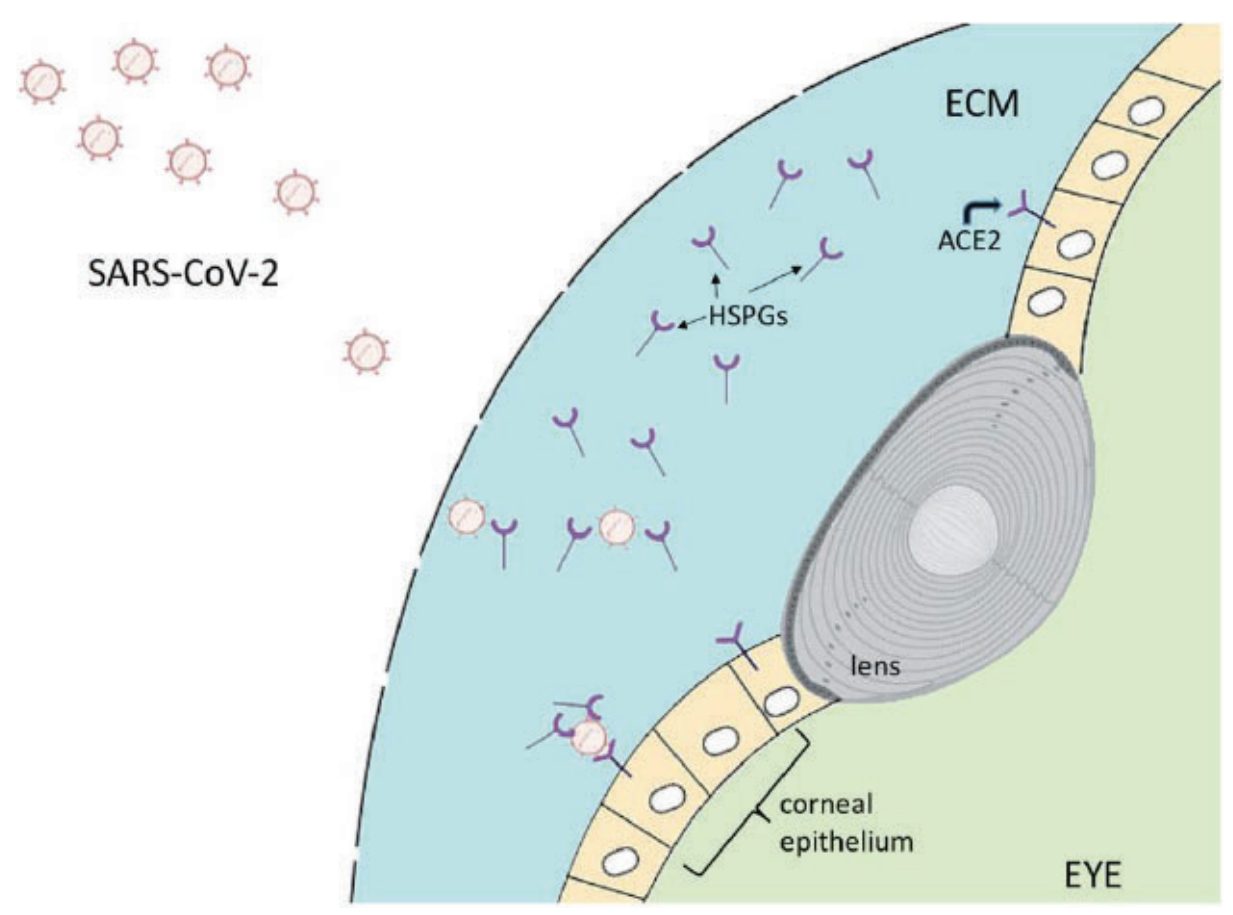

Gambar 2. Proses transmisi infeksi virus SARS-CoV-2 melalui konjungtiva dan epitel kornea. $^{9}$

antara frekuensi kontak tangan dengan mata dengan terjadinya konjungtivitis melalui analisis regresi multipel..$^{10}$ Pada penelitian cross-sectional oleh Sindhuja dkk., didapatkan bahwa dari 8 pasien dengan infeksi COVID-19, sebanyak 2 (25\%) pasien mengalami konjungtivitis tanpa adanya gejala COVID-9 sistemik, sedangkan sebanyak 6 pasien mengalami gejala sistemik. Dari 6 pasien tersebut, sebanyak satu pasien mengalami konjungtivitis satu hari sebelum gejala sistemik muncul, dua pasien setelah 1 minggu gejala sistemik, satu pasien setelah 2 minggu dan dua pasien setelah 3 minggu. ${ }^{11}$ Temuan berbeda didapatkan oleh Zhou dkk. yang meneliti korelasi temuan okuler dengan durasi penyakit, yang menemukan bahwa proporsi pasien dengan gejala okuler tidak berhubungan secara statistik dengan durasi penyakit. ${ }^{8}$

Penelitian oleh Güemes-Villahoz dkk. menemukan tidak adanya hubungan signifikan antara skor keparahan infeksi COVID-19 dengan konjungtivitis. Menilik hasil analisis studi, sebagian besar konjungtivitis pada infeksi COVID-19 ditemukan pada sampel berjenis kelamin laki-laki dan dengan derajat infeksi COVID-19 ringan-sedang. ${ }^{12}$ Median interval terjadinya onset COVID-19 dan konjungtivitis pada adalah 6 hari, dengan durasi konjungtivitis hingga terjadinya penyembuhan rata-rata satu minggu. Perjalanan alamiah konjungtivitis merupakan jenis konjungtivitis yang dapat sembuh dengan sendirinya yang dapat membaik tanpa pengobatan dan tidak mempengaruhi ketajaman penglihatan maupun adanya komplikasi berupa gangguan tajam penglihatan jangka pendek. Ditemukan pula keluhan yang paling sering dijumpai pada pasien infeksi COVID-19 dengan konjungtivitis yakni adanya sekret mukopurulen, epifora, dan sensasi benda asing pada mata. ${ }^{11-19}$ Dalam studi oleh Shamer dkk. juga menyatakan bahwa pasien COVID-19 lebih banyak mengeluhkan sensasi benda asing dan kemerahan pada mata. Konjungtivitis juga ditemukan berhubungan dengan adanya gangguan penciumandan pengecapanserta berhubungan dengan derajat keparahan penyakit yang lebih serius. Hubungan ini dapat dijelaskan melalui mekanisme keterlibatan okuler yang berhubungan dengan peningkatan jumlah virus pada rongga hidung. ${ }^{13}$ Penelitian oleh Wu dkk. menemukan bahwa konjungtivitis yang ditemukan pada 12 dari 38 pasien positif COVID-19 juga mengalami manifestasi okuler lainnya seperti hiperemi, kimosis, epifora, dan peningkatan sekresi. Dari segi data laboratorium, pasien COVID-19 dengan konjungtivitis ditemukan memiliki kadar sel darah putih, neutrofil, procalcitonin, C-reactive protein, dan lactate dehydrogenase yang lebih tinggi dibandingkan pasien COVID-19 tanpa gejala okuler. ${ }^{5}$ Temuan ini mendukung teori bahwa infeksi COVID-19 dapat disebarkan melalui mata.

Laporan kasus oleh Marquezan dkk. melaporkan adanya gambaran petekie dan pendarahan konjungtiva pada pasien terkonfirmasi COVID-19. Gambaran ini seringkali dijumpai pada penyakit mata akibat infeksi virus. Disebutkan bahwa saluran nafas bukan satu-satunya rute transmisi infeksi COVID-19. ${ }^{14}$ Hasil analisis sintesis studi juga menyebutkan bahwa konjungtivitis merupakan gejala awal terjadinya infeksi COVID-19, seperti yang dinyatakan pada studi Daruich dkk. yang melaporkan pasien laki-laki 27 tahun dengan keluhan sensasi benda asing dan kemerahan pada mata. Hasil pemeriksaan menunjukkan adanya edema kelopak mata unilateral dan hiperemi konjungtiva. Beberaja jam kemudian, pasien mengalami gejala tambahan berupa demam, batuk, nyeri kepala hebat, dan sesak nafas. Hasil pemeriksaan swab nasofaring kemudian menunjukkan positif COVID-19. ${ }^{15}$ Kasus tersebut menunjukkan bahwa konjungtivitis dapat menjadi gejala awal infeksi COVID-19 dimana kondisi hiperemia merupakan tanda awal terjadinya distress nafas berat.

Terdapat dua laporan kasus yang menemukan konjungtivitis sebagai satu-satunya manifestasi klinis infeksi COVID-19. Pertama penelitian oleh Scalinci dkk yang menyatakan bahwa konjungtivitis menjadi satu-satunya gejala COVID-19 pada lima pasien. Pada kelima pasien tersebut didapatkan gejala konjungtivitis akut, berupa hiperemis, epifora, dan fotofobia tanpa adanya demam, serta lemas maupun gejala respiratorik. Infeksi COVID-19 pada kelima pasien tersebut dikonfirmasi melalui pemeriksaan RT-PCR pada spesimen nasofaring. ${ }^{18}$ Kasus kedua adalah Ozturker dkk. yang menemukan konjungtivitis pada perawat laki-laki yang bekerja di UGD. Pasien awalnya berobat ke dokter mata dengan keluhan kemerahan, 
mata gatal berair, dan fotofobia pada mata kanan tanpa adanya gejala ekstraokuler lainnya seperti demam, batuk, sesak, maupun lemas. Karena pasien memiliki risiko sempat kontak dengan pasien terkonfirmasi COVID-19, maka tes RTPCR pun dilakukan dan didapatkan hasil positif. Swab pada konjungtiva juga dilakukan namun didapatkan hasil negatif. ${ }^{19}$ Laporan kasus oleh Navel dkk. juga menemukan hasil swab konjungtiva negatif pada pasien terkonfirmasi COVID-19 dengan konjungtivitis hemoragika yang muncul pada hari perawatan ke-19 di ICU. Hasil berbeda ditemukan pada laporan kasus oleh Nayak dkk. yang menyebutkan bahwa hasil swab sekret konjungtiva menunjukkan hasil positif terdeteksi virus SARS-CoV-2 pada pasien COVID-19 dengan konjungtivitis. Secara teori, permukaan bola mata merupakan tropisme yang baik untuk virus saluran nafas, dimana RNA coronavirus juga telah ditemukan pada sekret mata dan air mata. Namun viral load yang terdeteksi lebih sedikit dibandingkan dengan hasil swab dari spesimen saluran nafas. Hal ini mengindikasikan bahwa pengambilan spesimen dari konjungtiva bukanlah lokasi yang ideal untuk diagnosis COVID-19 dan tidak perlu rutin dikerjakan untuk semua pasien suspek COVID-19. Meski sekret konjungtiva tidak ideal untuk sebagai spesimen pemeriksaan RT-PCR, tetap terdapat kemungkinan adanya virus shedding pada rute konjungtiva. ${ }^{17}$

Secara teori, coronavirus jarang ditemukan pada air mata. Namun semenjak pandemik COVID-19, jenis coronavirus seperti SARS-CoV, HCoVNL63, dan SARS-CoV-2 telah banyak terdeteksi dari pemeriksaan RT-PCR. Sesuai dengan teori patogenesis yang telah dipublikasikan, virus SARS-CoV-2 memiliki reseptor yang mirip dengan virus SARS-CoV, yakni angiotensinconverting enzyme-2 (ACE2). Permukaan bola mata terdiri atas konjungtiva dan epitel kornea yang terhubung dengan saluran nafas atas. Cairan pada mata akan diabsorbsi oleh konjungtiva dan epitel kornea, kemudikan dialirkan dari hidung ke saluran nafas atas melalui kelenjar nasolakrimal. Hal tersebut menyebabkan pathogen daari mata dapat ditranspor ke sstem pernafasan. Yang menarik adalah, mata manusia memiliki sistem angiotensin intraokulernya sendiri dan reseptor ACE2 juga ditemukan pada aqueous humor mata dan sel epitel konjungtiva pada permukaan bola mata. Namun, ekspresi ACE2 pada permukaan mata manusia ditemukan lebih sedikit dibandingkan jaringan lain. Selain dipengaruhi faktor imun sel inang, efisiensi infeksi virus juga bergantung pada kecepatan infeksi dan reseptor virus pada sel membrane inang. Heparan-sulfate-proteoglycans (HPSG) diketahui sebagai reseptor pertama yang memfasilitasi virus untuk menempel pada sel epitel dengan jumlah reseptor ACE2 yang rendah. Proses entri virus kemudian dibantu oleh ACE2 dan terbentuk ikatan yang lebih stabil melalui ikatan dengan protein $S$ seperti ditunjukkan oleh Gambar 2. 8,9

Beberapa rangkuman rekomendasi terkait temuan konjungtivitis pada infeksi COVID-19 adalah pada COVID-19 gejala ringan dapat menyebabkan konjungtivitis bilateral. Dokter mata harus lebih waspada pada sekret konjungtiva yang berebihan sebagai sumber transmisi infeksi selama pemeriksaan mata. ${ }^{1,2}$ Penggunaan alat pelindung diri berupa googles atau face shield sangat direkomendasikan untuk digunakan pada praktik klinis seharihari. ${ }^{11}$ Adapun keterbatasan dari systematic review ini adalah keterbatasan jumlah sampel penelitian serta lebih banyak studi berupa laporan kasus yang diikutkan dalam analisis.

\section{SIMPULAN}

Meski konjungtivitis ditemukan hanya pada sebagian kecil kasus COVID-19, konjungtiva dapat menjadi salah satu rute transmisi infeksi COVID-19. Konjungtivitis dapat menjadi gejala awal terjadinya infeksi covid-19, lebih banyak pada COVID-19 gejala ringan-sedang, dan dapat sembuh dengan sendirinya. Penggunaan google atau face shield sama pentingnya dengan penggunaan masker dan handschoen untuk mencegah transmisi infeksi melalui sekret konjungtiva. Dengan diketahuinya mekanisme transmisi infeksi COVID-19 melalui konjungtiva mata, dokter mata dapat memainkan peran penting dalam deteksi dini gejala dan penatalaksanaan COVID-19 dengan lebih baik.

\section{KONFLIK KEPENTINGAN}

Penulis menyatakan tidak terdapat konflik kepentingan terkait publikasi dari artikel ini.

\section{PENDANAAN}

Penelitian ini tidak mendapat dana hibah dari pemerintah ataupun lembaga swasta lainnya.

\section{KONTRIBUSI PENULIS}

Penulis berkontribusi terhadap penelitian ini baik dari perencanaan hingga interpretasi dan penyusunan naskah publikasi.

\section{DAFTAR PUSTAKA}

1. Seah I, Agrawal R. Can the Coronavirus Disease 2019 (COVID-19) Affect the Eyes? A Review of Coronaviruses and Ocular Implications in Humans and Animals. Ocul Immunol Inflamm. 2020;28(3):391-395. doi:10.1080/09273948.202 0.1738501

2. Nasiri N, Sharifi H, Bazrafshan A, Noori A, Karamouzian M, Sharifi A. Ocular Manifestations of COVID-19: A Systematic Review and Meta-analysis. J Ophthalmic Vis Res. 2021;16(1):103-112. Published 2021 Jan 20. doi:10.18502/jovr.v16i1.8256

3. Amesty MA, Alió Del Barrio JL, Alió JL. COVID-19 Disease and Ophthalmology: An Update. Ophthalmol Ther. 2020;9(3):1-12. doi:10.1007/s40123-020-00260-y

4. Douglas KAA, Douglas VP, Moschos MM. Ocular Manifestations of COVID-19 (SARSCoV-2): A Critical Review of Current Literature. In Vivo. 2020;34(3 Suppl):1619-1628. doi:10.21873/invivo.11952

5. Wu P, Duan F, Luo C, et al. Characteristics of Ocular Findings of Patients With Coronavirus Disease 2019 (COVID-19) in Hubei Province, China. JAMA Ophthalmol. 2020;138(5):575578. doi:10.1001/jamaophthalmol.2020.1291

6. Lu CW, Liu XF, Jia ZF. 2019-nCoV transmission through the ocular surface must not be ignored. Lancet. 2020;395(10224):e39. doi:10.1016/S0140-6736(20)30313-5

7. Sarma P, Kaur H, Kaur H, Bhattacharyya J, Prajapat M, Shekhar N, Prakash A. Ocular manifestations and tear or Conjunctival swab PCR positivity for 2019-nCoV in patients with COVID-19: a systematic review and metaanalysis. 2020. doi:10.2139/ssrn.3566161

8. Zhou Y, Duan C, Zeng Y, et al. Ocular Findings and Proportion with Conjunctival SARSCOV-2 in COVID-19 Patients. Ophthalmology. 2020;127(7):982-983. doi: $10.1016 /$ j. ophtha.2020.04.028

9. Panoutsopoulos AA. Conjunctivitis as a Sentinel of SARS-CoV-2 Infection: a Need of Revision for Mild Symptoms [published online ahead of print, 2020 Jun 19]. SN Compr Clin 
Med. 2020;1-6. doi:10.1007/s42399-020-00360-

10. Chen L, Deng C, Chen X, Zhang X, Chen B, Yu $\mathrm{H}$, Sun X. Ocular manifestations and clinical characteristics of 535 cases of COVID-19 in Wuhan, China: a cross-sectional study. Acta ophthalmologica. 2020;98(8):e951-e959. doi:10.1111/aos.14472

11. Sindhuja K, Lomi N, Asif MI, Tandon R. Clinical profile and prevalence of conjunctivitis in mild COVID-19 patients in a tertiary care COVID-19 hospital: A retrospective cross-sectional study. Indian $J$ Ophthalmol. 2020;68(8):1546-1550. doi:10.4103/ijo. IJO_1319_20

12. Güemes-Villahoz N, Burgos-Blasco B, García-Feijoó J, et al. Conjunctivitis in COVID-19 patients: frequency and clinical presentation. Graefes Arch Clin Exp Ophthalmol. 2020;258(11):2501-2507. doi:10.1007/s00417020-04916-0

13. Shemer A, Einan-Lifshitz A, Itah A, DubinskyPertzov B, Pras E, Hecht I. Ocular involvement in coronavirus disease 2019 (COVID-19): a clinical and molecular analysis. Int Ophthalmol. 2021;41(2):433-440. doi:10.1007/s10792-02001592-1

14. Marquezan MC, Marquezam JP, Nascimento H, Chalita MR, de Freitas D, Belfort Jr R. Conjunctivitis Related to not Severe COVID-19: A Case Report. Ocular immunology and inflammation. 2020;1-3. Doi: 10.1080/09273948.2020.1837186

15. Daruich A, Martin D, Bremond-Gignac D. Ocular manifestation as first sign of Coronavirus Disease 2019 (COVID-19): Interest of telemedicine during the pandemic context. J Fr Ophtalmol. 2020;43(5):389-391. doi:10.1016/j.jfo.2020.04.002

16. Nayak B, Poddar C, Panigrahi MK, Tripathy S, Mishra B. Late manifestation of follicular conjunctivitis in ventilated patient following COVID-19 positive severe pneumonia. Indian J Ophthalmol. 2020;68(8):1675-1677. doi:10.4103/ijo.IJO_1682_20

17. Navel V, Chiambaretta F, Dutheil F. Haemorrhagic conjunctivitis with pseudomembranous related to SARSCoV-2. American journal of ophthalmology case reports. 2020;19: 100735. doi:10.1016/j. ajoc. 2020.100735

18. Scalinci SZ, Trovato Battagliola E. Conjunctivitis can be the only presenting sign and symptom of COVID-19. IDCases. 2020;20:e00774. doi: 10.1016/j.idcr.2020.e00774

19. Ozturker ZK. Conjunctivitis as sole symptom of COVID-19: A case report and review of literature [published correction appears in Eur J Ophthalmol. 2020 Aug 27;:1120672120956486]. Eur $J$ Ophthalmol. 2021;31(2):NP161-NP166. doi:10.1177/1120672120946287

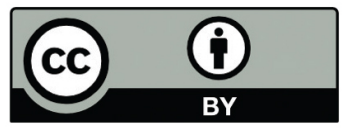

This work is licensed under a Creative Commons Attribution 